\author{
Citation: Kayral, İ. H. (2019), An International Strategy for Quality in Healthcare Beyond \\ Turkey: Three Country Review, BMIJ, (2019), 7(2): $926-945$ doi: \\ http://dx.doi.org/10.15295/bmij.v7i2.1111
}

\title{
AN INTERNATIONAL STRATEGY FOR QUALITY IN HEALTHCARE BEYOND TURKEY: THREE COUNTRY REVIEW
}

İbrahim H. KAYRAL ${ }^{1}$

\author{
Received (Başvuru Tarihi): 21/04/2019 \\ Accepted (Kabul Tarihi): 13/06/2019 \\ Published Date (Yayın Tarihi): 26/06/2019
}

\begin{abstract}
One of the main rights of the people is regarded as the equality in access to health services and its assurance. This study aims to examine the health care quality practices and cooperation potentials of the three countries, The Republic of North Macedonia, The Republic of Kosovo and Azerbaijan, within the framework of TÜSKA's international cooperation potential. The countries' potential for cooperation with Turkey reviewed by looking the overall structure of these countries, health systems, applications and quality are attempted to be addressed by examining future strategies. In addition to the basic factors such as cultural and historical relations, all three countries examined offer important cooperation opportunities in terms of the general structure of health systems and the countries' quality and accreditation objectives.
\end{abstract}

Keywords: Service Quality, Strategic Management, Healthcare

JEL Codes: M10, I11, M38

\section{TÜRKIYYE'NIN ÖTESINDE SAĞLIKTA KALITTE İÇIN ULUSLARARASI BİR STRATEJI: ÜÇ ÜLKE DEĞERLENDIRMESI}

$\ddot{O} Z$

Insanların temel haklarından biri sağllk hizmetlerine erişimde güvence ve eşitlik olarak kabul edilmektedir. Bu çalışma, TÜSKA'nın uluslararası işbirliği potansiyeli çerçevesinde ǚ ülkenin, Kuzey Makedonya Cumhuriyeti, Kosova Cumhuriyeti ve Azerbaycan'ın sağllk hizmetleri kalite uygulamaların ve işbirliği potansiyellerini incelemeyi amaçlamaktadır. Ülkelerin Türkiye ile işbirliği potansiyeli, bu ülkelerin genel yapısina bakılarak gözden geçirilmiş, sağllk sistemleri, kalite uygulamaları ve gelecek stratejileri incelenerek ele alınmaya çalışılmıștır. İncelenen her üç ülke de kültürel ve tarihi iliş̧iler gibi temel faktörlerin yanı sıra sağllk sistemlerinin genel yapısı, ve ülkelerin kalite ve akreditasyon hedefleri açısından önemli iş birliği firsatları sunmaktadır.

Anahtar Kelimeler: Hizmet Kalitesi, Stratejik Yönetim, Sağllk Hizmetleri

JEL Codes: M10, I11, M38

${ }^{1} \mathrm{PhD}$, Researcher, Turkish Healthcare Quality and Accreditation Institute, ikayral@gmail.com

https://orcid.org/0000-0003-1734-6844 


\section{INTRODUCTION}

In Turkey health services are being provided within more than 1,500 hospitals and other facilities for nearly 80 million people, by over 800,000 health staff. Many policies have been implemented in health system of Turkey since 2003. In 2003, MoH of Turkey declared "Health Transformation Program" (HTP) (Ministry of Health Turkey, 2003). One of the main parameter of the program is quality improvement in health care; quality and accreditation for qualified and effective health services. Ministry of Health has intended to improve satisfaction, to minimize a number of patient safety risks, helping to ensure health quality and patient safety on a national basis in health.

According to the OECD, the average of doctor admissions in Turkey is above the OECD average (OECD, 2015). There are 1,533 hospitals in Turkey with 210 thousand total beds number and 5,682 total operating rooms number. 660 million patient admissions was reached in 2016. Maintaining qualified healthcare services on a country scale requires systematic studies to reach the strategical aims (Ministry of Health Turkey, 2017).

Increase in patient expectations encourages the implementation of such programs that requires a consideration of both cost and quality issues simultaneously (Kayral, 2014). Especially under nature of complex health services, cultural transformation can only succeed if the necessary reforms are made continuously. The standardization of health services and accreditation of the hospital with external evaluation is necessary to provide high quality healthcare and patient safety. Turkish healthcare system conforms to international standards to ensure external evaluation system via accreditation programs. Heretofore developments have been finalized in accordance with some studies nationally and internationally that have been conducted in conjunction with ISQua (International Society for Quality in Healthcare) and WHO (World Health Organization).

All these efforts were designed to achieve a high quality level within healthcare system. As a result, healthcare is now designed with the national accreditation system. TUSKA (Turkish Health Care Quality and Accreditation Institute) has been set up to support healthcare accreditation in Turkey. The first accreditation program announced in 2017 and the first accreditation assessment applied in 2018 (TUSKA, 2019). According to the aims of the scientific boards of TUSKA, one of the main objective is to provide guidance and support for health care quality improvement and accreditation (Müezzinoğlu, 2014). 
Turkey has achieved important progress in improving quality of healthcare. In the journey of this improvement process, important knowledge and experience has been gained. However, this experience alone is not enough, it should be extended to other areas where healthcare is provided.

A group of studies in a book written by scholars, key policymakers, and specialits looking at the success stories with a future prediction of health systems (Braithwaite et al., 2017). One of the chapter in the book is related with quality and accreditation system in Turkey. It was mentioned about international quality and accreditation strategies of TUSKA with these ongoing sentences: "Turkey has close religious and cultural ties with much of the Muslim world, including Northern Cyprus, Macedonia, Kosovo, and Azerbaijan. Collaboration with countries such as Kazakhstan, Kirghizstan, Turkmenistan, Ukraine, and Moldova, are also possible, as Turkish is spoken in these countries. Indonesia, Kuwait, Saudi Arabia, Oman, Lebanon, and many other Muslim countries are also potential partners, and it is likely that various cooperative studies will be possible. Developments, protocols and advances can be shared and joint investments made. If these countries are linked more closely, the transfer of accreditation system designs and experience can be made across these different countries."

If we look at the quality and accreditation activities related with the above strategies, it was seen that TUSKA started these international policy steps with Northern Cyprus. According to these improvement, in this study, it is aimed to review and discuss other three countries that there is potential for international collaboration, accreditation system designs and experience sharing across these countries.

\section{METHODOLOGY}

Quality practices in health care delivery, whether at government level or at the hospital and health facility level, affect the satisfaction of users receiving health care. Beyond that, quality health care is the right of every citizen.

This study aims to examine the health care quality practices and cooperation potentials of the three countries selected from the countries listed above within the framework of TÜSKA's international cooperation potential.

In accordance with the purpose of the study; the first three countries mentioned in Braithwaite et al (2017) and the last one which studies have not yet started have been discussed. The countries' potential for cooperation with Turkey, the overall structure of these countries, 
health systems, applications and quality are attempted to be addressed by examining strategies for the future.

In this context, since the information and statistics infrastructure of the countries did not provide enough information, especially the country reports of the international organizations such as the World Health Organization, EU and the strategic plan documents of the countries were examined in particular within the framework of their quality and accreditation objectives.

\section{COUNTRY PROFILES}

For the management of the international collaboration strategies, country profiles play an important role. Factors like political and economic systems, population structure, religion and languages affects the success of relations between countries and also societies. In this point of view North Macedonia, Azerbaijan and Kosovo's country profiles will be reviewed respectively.

\section{The Republic of North Macedonia}

In 1991, Macedonia declared its independence from former Yugoslavia. In the process of market economy, the country has undergone a significant transformation process in both its political and economic structures (Gjorgjev et al., 2006).

The country is located on the Balkan Peninsula, in the southeast of Europe with population of 2.1 million. The Republic of Northern Macedonia, traditionally located in the northern part of the region known as Macedonia, is home to a large number of ethnic groups, including the Albanians, Turks, Vlachs and Roma, after 500 years of Ottoman Empire. In Macedonia, a complex border region between the major cultural traditions of Europe and Asia, Albanians are the majority in 16 of the 80 municipalities. Other minorities include Serbs, Bosniaks, Roma, Vlachs and Turks mostly settled in Northern Macedonia (Danforth, 2019).

Nearly one third of the population belongs to the Islamic religion, while most of the Slavic speakers in the Macedonian region are Orthodox Christians. The majority of both Albanians and Roma are Muslim as well as Turks.

Having a tough economic period after the Yugoslav civil war, Macedonia, however, began to find new trading partners in the early 1990s, and the economy began to improve. After independence, the country moved to parliamentary democracy and underwent a transformation from a planned economy to a market economy. However, the country is still one of the poorest countries in Europe (Freedom House, 2011). 
Macedonia, where unemployment levels are very high, despite the fall in unemployment rates after 2005, the unemployment rate is still 22.3\%. (World Bank, 2019).

\section{The Republic of Azerbaijan}

Located on the shores of the Caspian Sea, Azerbaijan's neighbor; the Islamic Republic of Iran, Armenia, Georgia, Russia and Turkey. Nearly half of the population, which is 9.86 million in 2017, lives in cities. Azerbaijan ranks 80th in the UN HDP Index (Human Development Reports, 2018).

The majority of the population is Muslim, and other religions in the country include Russian and Armenian Orthodoxy. The members of the Orthodox Church constitute a very small proportion. The official language of the state is Azerbaijani and Turkish speakers constitute about nine-tenths of the population (Edward et al., 2019).

The country has a young population with increasing population. Birth and mortality rates are below the global average and life expectancy of 73 years is world average. In the last few decades, a steady decline in fertility rates has been observed, and the demographic structure of the country, that has migrated in the 1990s, is changing and the population growth rate is decreasing. Although birth rates are falling, the country has a young population (World Bank, 2019).

Although the collapse of the former Soviet Union has an impact on the country's social and economic indicators, it is Azerbaijan's advantage to be among the major oil producers.

\section{The Republic of Kosovo}

Self-declared independent country, Republic of Kosovo lies in the Balkans. The population of the country was nearly nine tenths Albanian. One tenth of the population was Serb and remainder consists Bosniaks, Turks, Croats, Gorani, and Montenegrins. Kosova's official languages are Albanian and Serbian. Turkish, Bosnian and Romany have official status according to the 2008 constitution. Nine-tenths of the population including most of the Albanians are Muslim in the country (Allcock JB, 2019). According to the first census in 2011, excluding North Kosovo, the population had 1.74 million in the country (Statistical Agency of Kosovo, 2019).

The trade deficit of the country, which is one of the least developed and poor countries of the Balkans, increased significantly. The increase in trade deficit was due to the importation of food and fuel products from other countries (Allcock JB, 2019). 
Health services are being publicly subsidized by the public. On the other hand, many public clinics complain about inadequate personnel and equipment. Life expectancy in the country, which is 70 years for men and 80 years for women, is below the life expectancy of EU (Allcock et al., 2019).

As a result of the insufficiency of health facilities in the country, the people mostly receive these services from neighboring countries. Beyond this, the lack of adequate quality healthcare services provided by the state provides an opportunity for these services to be provided by US companies. As a result of this gap, American Hospital started to serve in Kosovo in 2015. Although there are public health institutions, these services are provided by the Serbian Government in the regions where Serbs are located.

\section{COUNTRYS' HEALTH SECTORS}

Before understanding and/or define strategies for quality and accreditation policies in health sector, the sector should have investigated with its different aspect of determinatives like age structure of populations, access to health services, providing of care, central authorities and health system in general with its insurance, regulations, economical system preferences and with its priorities.

\section{The Republic of North Macedonia}

The average life expectancy of the population is increasing day by day (75.1). This situation is also effective in the health system. When the increase rates were examined, the population above 65 years of age increased from $7.97 \%$ to $10.6 \%$ between 1990 and 2003, while the ratio of the population between the ages of 0-14 fell to $21.1 \%$. However, although the elderly population is growing, these rates still remain below the EU and Eastern and Central European countries. (World Health Organization, 2003).

Health care services offered in the country have a widespread network. This is a factor that public can access to health services facilitates easily. As in many other countries, the provision of health services in Macedonia begins with the primary health care service processes.

Secondary health care services are offered in general and private hospitals as well as in the practice and institutes, while tertiary health services are provided in clinical hospitals as well as in the University Clinical Center. The number of beds per person in Europe is 6.2. The capacity of approximately 10,000 beds in the country is below the EU average (4.8). A significant number of these beds are located in private hospitals and tertiary institutions (Health Strategy of Macedonia, 2007). 
According to data of Republic Institute for Health Protection, there are 17 specialized tertiary hospitals in Macedonia. There are 4 rehabilitation, 3 psychiatric and 10 other tertiary hospitals. There are 15 secondary health care, general hospitals (Health Strategy of Macedonia, 2007).

According to the data of 2013, a total of 73 health facilities are provided in four main categories that 65 of these health facilities are hospitals. These are distributed in 14 general, 4 clinical hospitals, 5 secondary health care facilities and 28 tertiary health care facilities. Longterm care is provided in 20 specialist hospitals and rehabilitation hospitals. (Institute of Public Health, 2015).

In the country, tertiary health services are provided only in Skopje. Other than that, all the major towns and cities include general hospital services. Hospital numbers are increasing with private capital investments. (WHO Regional Office for Europe, 2016).

Health service employment in 2013 is as follows; A total of 28,644 people work in public and private institutions. Of these employees, 5,804 are physicians, 1705 are dentists and 930 are pharmacists (HIF Annual Report, 2016).

Human resources in health services are not only quantitative but also qualitative. In this respect, the Ministry of Health, in the program launched with the support of WHO for the development of human resources in 2016, initiated studies to improve the level of education and specialization areas by taking into consideration the future plans.

After the independence of the country, we are faced with two major health policy periods. The first of these periods was the transition period after the socialism which lasted until 1991 in 1999. The second period is the period of market economy that started in 2000 and still continues.

Some basic steps have been taken in this period, which is aimed at establishing a free market economy. These steps include making third-party payments with the Health Insurance Fund (HIF), privatization of primary health care between 2004 and 2007, the establishment of the e-health system in 2006 and the Health Network in 2012. A significant majority of the population is under the umbrella of health insurance (85\%). Taking into account the needs in public health facilities, the government has made investments in the second period, especially for the improvement of these facilities. These investments have been shaped especially for the use of modern equipment in the facilities and the renovation of old facilities. 
A Health Network was established with the Law of Health Care published in 2012. With this network, it is aimed to use the resources in the sector effectively. Thus, it is aimed to enable everyone to reach equal health services, patient care, diagnosis and treatment processes. In support of the health network, the government has also implemented a number of applications. For example, the Health Insurance Fund only receives service from certified service providers. The Ministry of Health approves only those service providers who are involved in the network.

Many important decisions were taken before and after the health networks. For example, in 2008, Patient Rights were accepted and entered into force with a decision taken in 2008. Legal protection of patient rights can be seen as an important step in terms of patient safety and satisfaction (Bislimovska-Karadzinska et al., 2010).

In 2009, it was decided to establish a committee for the development of the health care system. Thus, it is aimed to increase access to health services and quality. This committee discusses important issues such as health care, health system management, financing, drug care and patient rights management (Chichevalieva and Milevska, 2012).

In 2015, the process of improving the health of the population was continued in order to support the policies implemented before. The strategies laid down in this context have been prepared taking into consideration the objectives of the WHO European Framework for Health and Well-being Health 2020 and the Sustainable Development Goals. The established strategies shape the 2020 vision of improving the health status of the public and the provision of health services in the country. One of the aim of the Health Strategy is: "Assurance of the quality and effectiveness of health services."

\section{$\underline{\text { The Republic of Azerbaijan }}$}

The Ministry of Health is the authority and responsible for the management of the health system in the country. Although the Ministry is responsible for health management in the whole country, it has local restrictions on the use of these responsibilities. These limitations are due to the fact that local health institutions are financed by the local authorities rather than by the Ministry. Private sector is growing day by day in the health system. Even though most of the health services are offered by the state, the Ministry adding the private sector institutions to the system by licensing them. (Ibrahimov et al., 2010)

Azerbaijan is a rich country in terms of hospitals. According to the figures of 1995, the number of beds of 9.1 per 1000 people is almost twice the EU average (4.9). Although this rate fell to 7.3 in 2007 , it is still a high rate. There are 733 hospitals in the country. Although there 
has been a decline between 1995 and 2007, the average length of stay in Azerbaijan is the largest in the WHO European Region. According to 2007 figures, the average length of stay in the country is 13.8. Although average residence times are high, bed occupancy rates are the lowest in the WHO European region due to the high number of beds per population in the country. (27.8\%) (WHO Regional Office for Europe, 2009).

In the health system, $\mathrm{MoH}$, local administrations and even limited private organizations are providing health services. In 2003, the state privatized 350 health institutions, most of which were dentistry and pharmacies. The Ministry has central institutions, hospitals and research centers. Local administrations provide services with district hospitals and polyclinics. The state finances the health institutions with the shares allocated from the local government budget.

A wide range of health services can be offered in private hospitals and clinics in Baku, the capital of the country. Civil society does not have a very effective role in the provision of health services. Oncology services, which is an important type of health service provision, are offered only in state hospitals.

Although local authorities finance many local service providers, the health system in the country is central. Azerbaijan has a well established health service with medical research institutes and specialized clinics services provided free to patients. System is financed by private payments and general tax revenues. Azerbaijan is in the process of mandatory health insurance system within the health reform. According to Azerbaijan 2020: a mandatory medical insurance system will be implemented, paying the way for effective procedures for providing quality medical services and patient rights protected. The system is being piloted in Yevlakh and Mingachevir with the target of expanding it to national level.

Citizens wishing to receive health services can receive services from any level of the health system depending on their geography, their own connections, and their power of payment. There is no formal system for patient routes, and although many health services are formally free, there are various fees for accessing patients (World Bank,2005).

\section{The Republic of Kosovo}

The Kosovo Ministry of Health (MoH) was established in 2002. In Kosovo, healthcare system is established in 3 levels. All municipalities have primary health services. Secondary health care services are provided by regional hospitals, but mental health centers also offer 
services. Tertiary services are offered by the Kosovo University. Dental clinic services are also provided at the same time in the university.

Tertiary level health institutions also serve as secondary level health institutions in Pristina. Beside public sector, the private health care network consisted of 1,069 licensed institutions in 2014, 305 of which are dental practices (Rashiti et al., 2019).

There were 4,092 beds in total, of which, 3,767 public beds and 325 beds in private institutions. Which means, 2.2 beds per 1000 inhabitants, that is less than half of the EU average (5.3). Also, there are 2.2 medical doctors per 1000 population, which is far below the average of EU 27 countries (3.4 doctors per 1000 citizens). The average daily bed occupancy rate is low. It was $62 \%$ in 2014. In hospitals there were on average 973 empty beds daily (Statistical Agency of Kosovo, 2014)

Average length of stay (ALOS) means the average number of days a patient stays in the hospital. A shorter stay can reduce the cost per patient released, however, shorter stays tend to be more in intensive services and cost much more per day. Kosovo has one of the lowest ALOS compared with the EU, with 6.9 days. Average bed occupancy rate (ABOR) shows how hospital are able to use capacity of beds. Since hospitals must have empty beds for treatment of emergency cases, ABOR must not be 100\%. In general, ABOR has decreased from $68.6 \%$ (in 2006 ) to $59.7 \%$ (in 2012) and is lower than the EU average (76.3\%). In Kosovo, in public hospitals on average every day there are 1,649 empty beds, compared with 1,232 of 2006. The Government of the Republic of Kosovo within the priority list of projects has incorporated a project to strengthen the primary care infrastructure. Primary health care network consists of 429 institutions, of which each municipality of Kosovo has the Main Family Medicine Centre as the main unit, with its constituent units of Family Health Centres and Family Health Ambulances (Republic of Kosovo, Ministry of Health, 2016),

According to the World Bank study in 2008 (Coper and Parkes, 2008), the entire network of health care is suitable for population size and short distance transportation in Kosovo. But based on analysis of the performance of health institutions reorganization and reevaluation of health institutions is needed for using them more effectively.

In Kosovo, the current health reforms consist of 4 pillars which started in 2010. The first introduces universal health insurance and the second introduces the Kosovo Hospital and University Clinical Services as a coordinating body for the delivery of health care. The last two pillars change the administrative role of the Ministry (Osmani et al, 2017). 
The Government (elected in June 2014) recognizes health as a priority sector and published a reform package including these main aims; improve financial protection and access to health services and improve quality, appropriateness and efficiency of health service delivery. Kosovo Hospital and University Clinical Services (KHUCS), established in 2014, as a coordinating body for the delivery. It is designed as a unitary health institution composed of all health care organizations. KHUCS have the status of autonomous units within it and can cover negotiations, analyses, management, planning and monitoring, quality and safety.

\section{DISCUSSION ON QUALITY AND ACCREDITATION POLICIES}

Population structures shape the demand for health services and continue to shift dynamically in all over the world. The population of world isn't only increasing but it's also ageing and migrating (United States Census Bureau, 2019). This gives the national and international authorities to support health services with the pre-accepted quality levels, especially for patient safety standards with their national authorities and institutions.

\section{The Republic of North Macedonia}

Although P4P is designed for effective use of restricted budgets, that based on pay for performance systems have been implemented on the amount and type of services rather than quality (Lazarevik and Kasapinov, 2012). Indicators or monitoring evaluation systems that follow quality improvement processes in health services were not established until 2014 (Agency for Quality, 2019).

In addition, clinical guidelines are used in the country to determine the clinical pathways in the health system. However, clinical guidelines do not focus on quality of care and do not measure quality.Information systems play an important role in the monitoring of clinical indicators. As the health information system infrastructure in the country is not yet sufficient, there are difficulties in providing the data infrastructure to monitor and measure the quality of care. This is also emphasized in the health information system strategies of 2007. With the MyAppointment information system, which was started to be implemented by the Ministry since 2013, it was aimed to keep health data more regularly.

Based on the deficiencies identified in the health system for the quality of care, the Ministry has established the Agency for Quality and Accreditation Care and Social Welfare. The Agency is responsible for preparing the standards, evaluating the health services provided within the framework of the quality of care standards and determining the application levels. 
As a result of the evaluations made, health institutions are accredited by the independent Agency if they are considered adequate. The accreditation services offered by the Agency aim to ensure the quality of the health services provided. These activities, which are intended to be identified, are stated in Act on Quality of Health Care. According to the National Health Care Strategy for 2012-2020, the Agency has a key role in determining the quality priorities (Agency for Quality, 2019).

Also there is another Institute for Accreditation of the Republic of North Macedonia (IARM, 2019) for accreditation. The base for the activities in the scope of accreditation, testing, certification and control are the standards of the EN 45000 and ISO 17000 series. IARM is an organized authority operating according to the standard MKC EN ISO/IEC 17011.

\section{The Republic of Azerbaijan}

Quality of health services and access to healthcare has an important effect on health outcomes. For instance, only half of citizens uses health services if they are ill, which indicate that people either will not or cannot pay for services with poor quality.

The lack of systemic proactive reforms has had important effects on the service quantity and service quality. When the patient pays more and on the other hand receive less with their payment, it makes them dissatisfied and patients lost confidence to the health system for providing enough care to restore their health.

Analytical Expertise Centre (AEC) is responsible for assessing and increasing the quality, safety and standards. Medicines effectiveness, quality and safety are controlled by AECM (the Department of Analytical Expertise of Medicines).

Standardization in health service delivery is important at the quality level. The Ministry is responsible for the preparation and implementation of quality standards in health care delivery. The implementation of the standards in health facilities is provided by local authorities. However, the results are not presented as a quality report. There are insufficient tools to encourage implementation. There is no systematic approach to monitoring and improving quality for both state and private institutions (Katsaga and Kehler, 2008) and there isn't any system to monitor patient safety in national level. Although there is no national system for health care quality or patient safety practices, clinical guidelines are used to increase the quality of care. Volunteerism is essential in the use of clinical guidelines.

Patient-centered services are also related with regulations that granted patient rights. Some basic rights offered to the citizens by law can be summarized as follows: the right to 
choose physicians, the right to diagnose and treat in a safe environment, the consent of the patient, the right to reject the intervention and the right to information.

Finally, looking at quality issues more closely (Ibrahimov et al., 2010), there are not given sufficient attention to the systematic measures for the quality of health service delivery. Lack of centralized and systematic initiatives hampers evidence of service quality. The infrastructures of health facilities are not sufficient to meet hygiene requirements. Problems such as inadequate updating of the skills of the health personnel and insufficient equipment and materials in medical education negatively affect the quality of service provision. This situation becomes permanent when the insufficiency of motivation factors for health personnel is added.

Azerbaijan is a country rich in underground resources. This makes it easier to allocate resources for health services and offers important opportunities to improve the quality of service delivery.

\section{The Republic of Kosovo}

The quality of health care services comprises of two main elements, patient satisfaction and the clinical. Research shows that hospital infection rates is high in Kosovo (Raka et al, 2006). The high rate of infections in neonatal units is the result of insufficient measures to control and prevention of hospital infections in the following points: equipment and medical equipment maintenance and hand hygiene, insufficient interdisciplinary cooperation and inter institutional coordination and weaknesses in internal management. Ministry undertakes some activities in the field of infection control. These are; development of guidelines and protocols for the control of hospital infections, strengthening of laboratory capacity, provision of legal infrastructure and institutionalization of Hospital Infection Councils.

Kosovo Hospital and University Clinical Services is responsible for providing quality health care services by focusing on efficiency, effectiveness, performance and transparency. Treatment guidelines and protocols, especially of chronic diseases, and monitoring of quality indicators will optimize the use of other services and procedures at the primary level and will improve the performance of health professionals. The aim of all these activities is to improve the cost effectiveness, quality and safety within the treatment of patients through strengthening the transfer of competences to the primary health care professionals.

The other component, patient satisfaction, is a very important parameter for evaluating the way services are provided, the environment and manner how healthcare professionals treat 
patients. In Kosovo, $84 \%$ of patients have considered received services as good to excellent, of which $81 \%$ for the public health sector and $94 \%$ for the private sector (UNDP, 2013)

The Ministry of Health aims to implement the obligations deriving from the Stabilization and Association Agreement (SAA) that represent the important priority of Kosovo in the process of EU integration. Kosovo Health Sector Strategy 2017-2021 in the framework of the activities envisaged gives priority to enforcement measures and legislative measures that are part of the National Plan for the Implementation of the SAA with the aim of achieving the necessary health standards as defined. Ministry of Health has also signed cooperation agreements with several countries and health institutions abroad that provide various modalities of cooperation for the delivery of health services.

Also, in Health Sector Strategy 2017-2021, there are some specific objectives for ensuring quality and safety. These are reducing the incidence of infectious diseases, taking measures to prevent hospital infections implemented, increasing the level of implementation of hand hygiene to $65 \%$, providing accessible and equal health services, achieving continuous improvement of quality and safety with accreditation, implementing health care standards in $80 \%$ of institutions in secondary and tertiary level. Finally, implementation of the selected standards from Quality Division Report by the end of 2017 and accomplishment of national accreditation plan by the end of 2019 are other objectives for ensuring quality and safety.

\section{CONCLUSION}

Geographically three countries are close to Turkey. As historically all has a relation with the incorporation with Ottoman Empire. North Macedonia, where Muslims are about one third of the society, is a region that hosts Albanians, Vlachs, Roma and Turks in Ottoman rule for a long time. A significant number of Turks settled in the western and central regions of Northern Macedonia. The former Soviets had important affects on social and economic variables in the country. Azerbaijan is one of the oil-producing countries in the world. The society is mostly Muslim and Azeri.Turkic is state's official language. The population of Kosovo consists of Albanians, Turks, Goranis, Bosniaks, Serbs and Romans. Turks, Bosnians and Roma are officially recognized. Nine-tenths of the population, mostly Albanians, is Muslim. Kosovo mostly have economic relations with North Macedonia, Germany, Serbia, China and Turkey.

The population of Macedonia has easy access to health services. Not only primary care, secondary and tertiary care services are also available for the population. Both public and private health institutions serve in the country. However, the bed capacity of the country at 
almost 10,000 levels is below the EU average (6.2 beds per 1000 people). In Macedonia there are 4.8 beds per thousand people. The number of hospitals in the 1990s increased by $50 \%$ per year. In 2013, the number of hospitals offering service in four different areas reached to 73. They serve as general and clinical hospitals, second and tertiary hospitals. General hospitals are provided in every major local town, while in large cities (Bitola, Tetovo and Shtip) clinical hospitals are available.

Local governments play an important role in the Azerbaijani health system. The financing and ownership of health service delivery is in these administrations, but the central government plays the role of the basic regulator of the health system. The Ministry of Health is responsible for the management of the health system in the country. Although the private sector is developing, the health service delivery in Azerbaijan is carried out mostly by the state. Private sector is licensed by the $\mathrm{MoH}$. In the country, privatization practices in health services are very limited. A large part of the private health facilities is located in the capital Baku. Azerbaijan has high values in terms of hospital bed capacity. 733 hospitals in the country have 9.1 beds per thousand people. This ratio is almost twice the EU average $(4,9)$ in 1995. Although the bed capacity has decreased to 7.3 in 2007 , the ratio is still high. The average length of stay in health institutions is also above the WHO European region.

In Kosovo, where the provision of services in the first, second and tertiary levels took place, the Ministry of Health has been managing the country's health system since its establishment in 2002. All municipalities have primary health care institutions. Regional health facilities offer secondry health care services in Kosovo. The University of Kosovo offers many clinics and institutes as well as tertiary care services. Kosovo Hospital and University Clinical Services (KHUCS), established in 2014, as a coordinating body for the delivery. It is designed as a unitary health institution composed of all secondary and tertiary health care facilities. KHUCS have the status of autonomous units within it. KHUCS, as an operative body, can cover negotiations, analyses, management, planning and monitoring, quality and safety. There were 4,092 beds totally, of which, 3,767 public beds (2020 in secondary care and 1,747 in tertiary institutions) and 325 beds in private institutions.

As is look at macro policies for health system of these three country, it could be seen that there are central strategies to improve health sector. Macedonia set up the Health Network in 2012 to ensure efficiency in health care services and efficient planning of resources. During the reform period in which free market mechanisms were established, the government also 
made investments to strengthen the infrastructure and equipment of public facilities. The 2020 vision strategies for the Macedonian health system have been developed, especially on the health status of the community and on improving health care services. One of the aim of the Health Strategy is: "Assurance of the quality and effectiveness of health services." Azerbaijan makes health insurance compulsory within the scope of health system reform. According to Azerbaijan 2020, a development concept health system: a mandatory medical insurance system will be implemented, paying the way for effective procedures for providing quality medical services and protecting patient rights. In Kosovo, the Government (elected in June 2014) recognizes health as a priority sector and published a reform package including these main goals; improve financial protection and access for the population and improve healthcare quality, appropriateness and efficiency of health service delivery.

Indicators or monitoring evaluation systems that follow quality improvement processes in health services were not established until 2014. In addition, clinical guidelines are used in the country to determine the clinical pathways in the health system. However, clinical guidelines do not focus on quality of care and do not measure quality. Information systems play an important role in the monitoring of clinical indicators. This is also emphasized in the health information system strategies of 2007. With the MyAppointment information system, which was started to be implemented by the Ministry since 2013, it was aimed to keep health data more regularly. Based on the deficiencies identified in the health system for the quality of care, the Ministry has established the Agency that is responsible for preparing the standards, evaluating the health services provided within the framework of the quality of care standards and determining the application levels. Also there is another Institute for Accreditation of the Republic of North Macedonia (IARM) for accreditation. The base for the activities in the scope of accreditation, testing, certification and control are the standards of the EN 45000 and ISO 17000 series.

Analytical Expertise Centre (AEC) is responsible for assessing and increasing the quality, safety and standards in Azerbaijan. Quality, safety and effectiveness of medicines are regulated by the AECM. Although the ministry determines quality standards to standardize the quality levels of health facilities in the country, the implementation and monitoring of these standards are carried out by local authorities. However, there are no systematic practices for evaluating service quality.

In Kosovo, hospital infection rates are high. The high rate of infections in neonatal units is the result of insufficient measures to control and prevention of hospital infections. Ministry 
undertakes some activities in the field of infection control. These are; development of guidelines and protocols for the control of hospital infections, strengthening of laboratory capacity, provision of legal infrastructure and institutionalization of Hospital Infection Councils. Kosovo Hospital and University Clinical Services is responsible for providing quality health care services by focusing on efficiency, effectiveness, performance and transparency Also, in Health Sector Strategy 2017-2021, there are some specific objectives for ensuring quality and safety.

Health services are complex services that serve both the nature of the service and the many variables ranging from public authorities to service providers. Considering these challenges in a health system supported by long-term strategic plans is a must for quality health service delivery. Standardization and accreditation are becoming more important in this respect, especially in the country's equal access to health services.

In this study, it is aimed to review and discuss selected three countries that there is potential for international collaboration, accreditation system designs and quality experience sharing across these countries.

In addition to the basic factors such as cultural and historical relations, all three countries examined offer important cooperation opportunities in terms of the general structure of health systems and the countries' quality and accreditation objectives. These areas; common quality improvement practices, joint hospital practices in terms of information sharing, accreditation of hospitals with the best patient safety practices or pilot studies in these hospitals.

At the same time, it would be advisable to establish information systems infrastructures for the sharing of clinical or basic quality indicators in the common areas by establishing regional associations based on the effectiveness of the joint studies with these countries. 


\section{REFERENCES}

Agency for Quality and Accreditation of Health Care and Social Welfare, 2019, web site: http://www.aaz.hr/en/about-us, (accessed 27 March 2019)

Allcock JB, Young A, Lampe JR (2019),. Kosovo Self-Declared Independent Country, 2019, Britannica Articles, https://www.britannica.com/place/Kosovo, (accessed 02 April 2019)

Azerbaijan: Human Development Indicators in human development reports. New York: United Nations Development Programmes; 2018 (http://hdr.undp.org/en/countries/profiles/AZE, (accessed 11 April 2019).

Braithwaite J, Mannion R, Matsuyama Y, Shekelle P, Whittaker S, Al-Adawi S. (2017), Health Systems Improvement Across the Globe: Success Stories from 60 Countries Retrieved from Berktaş and Kayral, "Turkey Establishment of a National Healthcare Accreditation System" 6000 Broken Sound Parkway NW, Suite 300 Boca Raton, FL 33487-2742 CRC Press 2017

Chichevalieva S, Milevska N (2012). Participatory democracy in public health: committee for healthcare system advancement in Macedonia. Journal for European Issues Evrodijalog, 17:187-204.

Coper L, Parkes A, (2008), Government of Kosovo World Bank Health Sector Master Planning

Danforth L. (2019), North Macedonia, Britannica Articles, https://www.britannica.com/place/North-Macedonia, (accessed 18 March 2019)

Edward AG. Ronald MH, Suny G, Evgeny Dmitrievich Silaev ED. (2019), Azerbaijan, https://www.britannica.com/place/Azerbaijan.

Freedom House (2011). Nations In Transit 2011: country report on Macedonia, Washington, Freedom House. (http://www.freedomhouse.org/report/nations-transit/2011/macedonia, (accessed 16 March 2019)

Gjorgjev D, Bacanovic A, Cicevalieva S, Sulevski Z, Grosse-Tebbe S. (2006), The former Yugoslav Republic of Macedonia: health system review. Health Systems in Transition, 8(2):1-98.

Health Strategy of the Republic of Macedonia, 2020 Safe, Efficient and Just Health Care System (2007), Republic of Macedonia Ministry of Health

HIF Annual Report, (2016), Health Insurance Fund Annual Report 2015, http://www.fzo.org.mk/WBStorage/Files/Godisen\%20izvestaj\%202015.pdf, (accessed 25 March 2019).

Ibrahimov F, Ibrahimova A, Kehler J, Richardson E. (2010) Azerbaijan: Health system review. Geneva, World Health Organization, Health Systems in Transition, Vol.12. No.3

Institute for Accreditation of the Republic of North Macedonia, (2019), IARM web site: http://iarm.gov.mk/ (accessed 07 March 2019).

Institute of Public Health (2015). Utilisation of the hospital facilities in the Republic of Macedonia in 2014

J. Bislimovska-Karadzinska, J. Dabovic-Anastasovska, S. Chichevalieva, et al., Human rights in patient care: A practitioner guide - Macedonia (Skopje, Republic of Macedonia: Medical Faculty, Ss. Cyril and Methodius University and Centre for Regional Policy Research and Cooperation Studiorum, 2010)

Katsaga A, Kehler J, (2008), Report: WHO mission to evaluate the quality of data for the purpose of assessing health system performance. Baku, WHO Regional Office for Europe 
Kayral, İ, (2014), Perceived service quality in healthcare organizations and a research in Ankara by hospital type. Journal of Ankara Studies, 2(1), 22-34

Lazarevik V, Kasapinov B (2012). Medical doctors' attitudes towards pay-for-reporting in Macedonia medical doctors' attitudes towards pay-for-reporting in Macedonia: a web-based cross-sectional survey. Macedonian Journal of Medical Sciences 5(4):437-443

Ministry of Health Turkey, (2003), Health Transformation Program (HTP). Ankara, Turkey: Ministry of Health

Ministry of Health Turkey, (2017), Health Statistics Yearbook: 2016. Ankara, Turkey: Ministry of Health

Müezzinoğlu, M, (2014), Minister of Health of Republic of Turkey, Presidency of Health Institutes of Turkey workshop speech, presented at İstanbul, Turkey

OECD, (2015), (Organisation for Economic Co-operation and Development). Health Note: How does Health Spending in Turkey Compare? Retrieved from https:// www.oecd.org/els/health-systems/Country-NoteTURKEY-OECD-HealthStatistics-2015.pdf (accessed 02 March 2019)

Osmani A, Marušǐc D, Halimi R, Muharremi R, and Rupel V. (2017), Euro Health Systems and Policies, Euro Health incorporating Euro Observer Vol.23 | No.1 | 2017

Raka L, Zoutman D, Mulliqi G, Krasniqi S, Dedushaj I, Raka N, Ahmeti S, Shala M, Vishaj A, Elezi Y., (2006), Prevalence of nosocomial infections in high-risk units in the university clinical center of Kosova, Infect Control Hosp Epidemiol. 2006 Apr;27(4):421-3. Epub 2006 Mar 24

Rashiti A, Svarça L, Kurti A, Rashiti P. (2019), Awareness, knowledge and attitude toward secondary health care system: survey of physicians in Kosovo, Bangladesh Journal of Medical Science Vol. 18 No. 02 April'19

Republic of Kosovo, Ministry of Health, (2016), HEALTH SECTOR STRATEGY 2017-2021

Statistical Agency of Kosovo, (2019), http://ask.rks-gov.net/en/kosovo-agency-of-statistics, (accessed 2 April 2019)

Statistical Agency of Kosovo. Health System, Social Statistics (2014), Health Statistics, Series 5. Prishtina, Kosovo, 2014

Turkish Health Care Quality and Accreditation Institute, (2019), Announcements, Retrieved from https://www.tuseb.gov.tr/enstitu/tuska/index.php?lang=en (accessed 08 March 2019)

UNDP, 2013, Action Paper On Healthcare in Kosovo, Satisfaction with Healthcare Services and Perceptions on Presence of Corruption, November, 2013, Written; Fitim Uka - Lead Analyst and Festina Balidemaj Analyst

United States Census Bureau, (2019), U.S. and world population clock. https://www.census.gov/popclock/ (accessed 10 March 2019)

WHO Regional Office for Europe, (2009), European Health for All database, August 2009 edition Copenhagen, WHO Regional Office for Europe

WHO Regional Office for Europe, (2016), European Health for All Database 
World Bank, (2005), Azerbaijan health sector review note, Vol. I: Main report. Washington, DC, International Bank for Reconstruction and Development, World Bank

World Bank, (2019), World Bank development indicators database 2016. Washington DC, World Bank (http://data.worldbank.org/products/wdi, (accessed 30 March 2019)

World Health Organization, (2003), Regional Office for Europe, Country Office Skopje. Report on workshop on health systems and policies in the former Yugoslav Republic of Macedonia. Skopje, 27-28 November 2003 